\title{
Oxalate Content of Some Spices and Seasonings of South-Eastern Nigeria
}

\author{
V. O. Njoku, C. Obi and G. A. Obodo \\ Department of Chemistry, Imo State University, P.M.B. 2000, Owerri, Nigeria. \\ E-mail: viconjoku@yahoo.com.
}

\begin{abstract}
The oxalate content of fresh and dry samples of local spices and seasonings were determined. Oxalate contents were for fresh weight of the spices and seasonings: African red pepper (119.07 mg/100g); ginger (132.07 $\mathrm{mg} / 100 \mathrm{~g})$; fermented melon (315.19 mg/100g); garlic (199.72 mg/100g); beet leaves (514.80 $\mathrm{mg} / 100 \mathrm{~g})$ and for pepper fruit, the riped seed $(78.30 \mathrm{mg} / 100 \mathrm{~g})$, riped coat $(126.75 \mathrm{mg} / 100 \mathrm{~g})$, unriped seed $(229.69 \mathrm{mg} / 100 \mathrm{~g})$, unriped coat $(153.37 \mathrm{mg} / 100 \mathrm{~g})$. The oxalate contents for the dry weights were: African red pepper (130.03 $\mathrm{mg} / 100 \mathrm{~g}) ;$ ginger (138.82 mg/100g); fermented melon (486 mg/100g), garlic (210.28 mg/100g); beet leaves (600 $\mathrm{mg} / 100 \mathrm{~g})$ and for pepper fruit, the riped seed $(227.67 \mathrm{mg} / 100 \mathrm{~g})$, riped coat (330.34 mg/100g), unriped seed $(400.49 \mathrm{mg} / 100 \mathrm{~g})$ and unriped coat $(238.14 \mathrm{mg} / 100 \mathrm{~g})$. This revealed that the oxalate contents of dry samples were higher than those of the fresh samples. Therefore, it is safer to eat high oxalate foods fresh to avoid the risk of hyperoxaluria, goitre and all attendant consequences of oxalate poisoning.
\end{abstract}

Keywords: Spices, seasonings, oxalate, fresh weight, dry weight.

\section{INTRODUCTION}

Spices are products of plant origin used primarily for the seasoning of foods to give it flavour and aroma. Historically, the term "spice" is applied only to certain fruits, roots or barks grown in the tropics (Oyenuga, 1968). Today the spice industry has many other products which include herbs, aromatic seeds, dehydrated seasoning, vegetable, blends and salts. Seasonings are applied to blends of spices which may or may not contain other ingredients such as onions, garlic, etc. African red pepper (Capsicum annum) belongs to the family of Solanaceae. It is a red pod-like fruit. The plant is a herb cultivated extensively in all tropical countries. Ginger (Zingiber officinale) belongs to the family of Zingiber aceae. It is a small erect perennial herb. It is considered to be the most important of all spices and condiments; and is used all over the world as a condiment to give aromatic hot taste to curries and various fruit and vegetable preserves. Pepper fruit (Denitta tripetale) belongs to the family of Annonaceae and is a tropical tree common in the mangrove forests of the west coast of Africa. It flourishes at the beginning of the rainy season especially during the months of April and May. The mature fruits (ripe and unripe) constitute the major edible portion. However, some communities in some parts of country, Nigeria (Southern Nigeria) also utilize the leaves and the roots in addition to the fruits for medicinal purposes. Melon (Ciltrulus vulgaris) belongs to the family of Curbitaceae. It is known widely in the tropics and also in temperate regions of the world where it requires a lot of heat and sunshine. The fermented melon is got from the melon. The fermented melon is referred to as "Ogiri" and is used to season or flavour soup (Nnanna, 1968). Garlic (Allum satirum) belongs to the family of Liliaceae. It is a strong smelling whitish bulb. The smell is due to the presence of a sulphur-containing volatile oil present in all parts of the plants. Beet 
(Costus afer) belongs to the family of Zingiberaceae. It is a specie of ginger and one of the 140 species of stout, perennial, rhizomatous herbs found in the tropics of both hemispheres.

Oxalate exists in plants in a crystalline form either as calcium oxalate or as a soluble anion (Holmes and Kennedy, 2000). The physiological role of oxalate in plants is not precisely known. It has been suggested that it is involved in seed germination, calcium storage and regulation, ion balance, detoxification, structural strength, and insect repulsion (Lane, 1994). Food substances worthy of consumption have nutritive values of great dietary effect which in the first place attract people to eat them. On the other hand, these same food substances may contain antinutritive substances (Massey et al., 2001). Spices and seasonings are no exception to these characteristics. As they contain the required nutrients, they also may contain some antinutritive substances which may or may not be in trace amounts. These phytotoxins include: antivitamins, tannins, oxalates, phytates, cyanogenic glycosides, haemaglutinins, phytohormones and the alkaloids (Munro and Bassir, 1969).

Oxalates are dicarboxylic acid anions produced and accumulated in many crops, plants and pasture weeds. Oxalates may be present in plants as the soluble salts of potassium (K) and sodium (Na), ammonium $\left(\mathrm{NH}_{4}{ }^{+}\right)$salts, oxalic acids or as insoluble calcium oxalates (Nnanna, 1968). Certain plant foods contain appreciable amounts of oxalates: spinach, 0.30-1.29\%; rhubarb, 0.20-1.30 \%; beet leaves, 0.30-1.00\%; tea, 0.30-2.00\%; and cocoa, 0.50-0.90\% (Fasset, 1973). Other foods known to contain high oxalate levels include nuts (42-469 mg/100 g) (Ritter and Savage, 2007); legumes (4-80 mg/100 g) and flours (37-269 mg/100 g) (Chai and Liebman, 2005). Noonan and Savage (1999) and Charrier et al. (2002) have also shown that chocolate, wheat bran and strawberries also contain oxalate levels. Curham (1999) has shown that on a dry weight basis, some of the Nigerian vegetables might be superior to milk as gross sources of calcium, except that the calcium is not available due to the presence of oxalic acid, but is bound as insoluble calcium oxalate.

Oxalate is a concern because high oxalate diets can increase the risk of renal calcium absorption. Two general reviews of plant oxalates and their biochemistry and toxicity have been contributed by Curham (1999) as well as by Fasset (1973). The oxalic acid content of a large number of vegetables and fruits consumed in the southern parts of Nigeria was determined by Nwaiberi-Onunuju (1996) and Munro and Bassir (1969). Literature has shown that foods which contain these oxalates produce chronic effects which include: the deposition calcium oxalate crytals in the kidney known as nephrolithisis (kidney stones) (Concon, 1988; Holmes and Kennedy, 2000), and the occurrence of stones in the urinary tracts (Parker, 1980). From the researches carried out by Liebman (2002), it was found that these oxalates also cause vulvar pains in women. Research has revealed that the injection of 4-5 grammes of oxalate is the minimum dose capable of causing death in adults (Linder, 1991) but reports have also shown that 10-15 grammes is the usual amount which results in corrosion of the mouth and 
gastrointestinal tract, gastric haemorrhage, renal failure and haematuria. Another associated problem is low plasma oxalates which may cause convulsion (Watanebe et al., 1994). It is therefore imperative to ascertain the level of oxalates in the locally consumed spices and seasonings to avoid cases of death and abnormalities, hence, the thrust of this study. This study aims at determining the oxalate content of fresh and dry samples of spices and seasonings of South Eastern Nigeria and thereby determining the effect of drying on the oxalate levels of these food items.

\section{MATERIALS AND METHODS}

\section{Sample collection and preparation}

African red pepper, ginger, fermented melon, garlic, riped and unriped pepper fruit were collected from Eke-Onunwa market, Owerri while beet leaves were collected from Ameshi Oguta, in Oguta Local Government Area of Imo State. The samples were prepared in both fresh and dry weights for the objectives of this study. For dry samples, it was collected and dried under sunlight for 6-7 days to remove moisture content to at least $98 \%$ and then finally ground to powdered form. The wet samples were washed with clean water and ground. This is to avoid fermentation processes that will affect the level of oxalate in these samples.

\section{Analysis}

The samples were analysed adopting the methods of Andrew and Visser (1951). Six grammes each of the dry samples and $12 \mathrm{~g}$ each of the fresh samples were weighed out and each digested with $150 \mathrm{ml}$ of $3 \mathrm{M} \mathrm{HCl}$ for about 30 minutes. The solution was cooled, filtered and the filterate made up to $100 \mathrm{ml}$ using de-ionized water. Before precipitation, the solution was adjusted to a $\mathrm{pH}$ of 7.0 using aqueous ammonia. To this, a solution of saturated $\mathrm{CaCl}_{2}$ was added to double the volume. A slight white colouration was observed and this indicated the presence of low concentration of oxalate ion. The solution was then kept overnight in a water bath at a temperature of $60{ }^{\circ} \mathrm{C}$. It was centrifuged and the precipitate collected in the test tube by decanting the supernatant liquid. Finally, the precipitate was dissolved in $10 \mathrm{ml}$ of $0.5 \mathrm{M}$ $\mathrm{H}_{2} \mathrm{SO}_{4}$ and the solution made up to $50 \mathrm{ml}$ using $\mathrm{H}_{2} \mathrm{SO}_{4}$. The solution was left overnight to remove the white precipitate formed completely. The resulting filterate was transferred quantitatively into a $250 \mathrm{ml}$ conical flask. Then a $25 \mathrm{~cm}^{3}$ of the solution was pipetted into a conical flask, and heated to about $70{ }^{\circ} \mathrm{C}$ and titrated with $0.02 \mathrm{M} \mathrm{KMnO}_{4}$. Heating continued until a permanent pink colouration was observed (Andrew and Visser, 1951). The titration was repeated for at least two times and the average value was taken.

\section{Results and Discussion}

Figures 1 and 2 illustrate the oxalate contents of the various spices and seasonings for dry and fresh weights respectively. For both the dry and fresh weights, it was observed that beet leaves (Costus afer) contains the highest oxalate values of $600.00 \mathrm{mg} / 100 \mathrm{~g}$ and $514.8 \mathrm{mg} / 100 \mathrm{~g}$ respectively. The least oxalate content was observed for the dry weight samples in African red 
pepper having value of $130.03 \mathrm{mg} / 100 \mathrm{~g}$. For the fresh weight samples, the least oxalate content was observed in riped seed of pepper fruit having a value of $78.03 \mathrm{mg} / 100 \mathrm{~g}$.

The results reveal that the dry weight samples have higher oxalate contents than their fresh counterparts. It has been reported that the consumption of large amounts of plant oxalate and its absorption can be fatal to both humans and other animals because of oxalosis, the formation of calcium oxalate deposits in body tissues (Sanz and Reig, 1992). It was indicated that over 1 $\mathrm{g}$ of oxalate per $100 \mathrm{~g}$ of sample is dangerous to health and that the consumption of 4-5 $\mathrm{g}$ of oxalate can cause death in adults. Allison et al. (1995) reported that as much as 10-15 g of oxalate were required to cause fatalities. The highest oxalate content in the test samples is 0.6 $\mathrm{g} / 100 \mathrm{~g}$ sample, indicating that all the samples are safe for human consumption. The conclusion to stand include that foods containing oxalates are better consumed fresh as drying increases the oxalate level and that different parts of the plant system contain different levels of oxalate. High oxalate in the body could cause hyperoxaluria and goiter (Watanebe et al., 1994; Andrew and Visser, 1951). High levels of oxalate could limit the level of calcium in the body (Curham, 1999). People with fractures as well as the aged should limit high consumption of dried foods since calcium is required for bone repair.

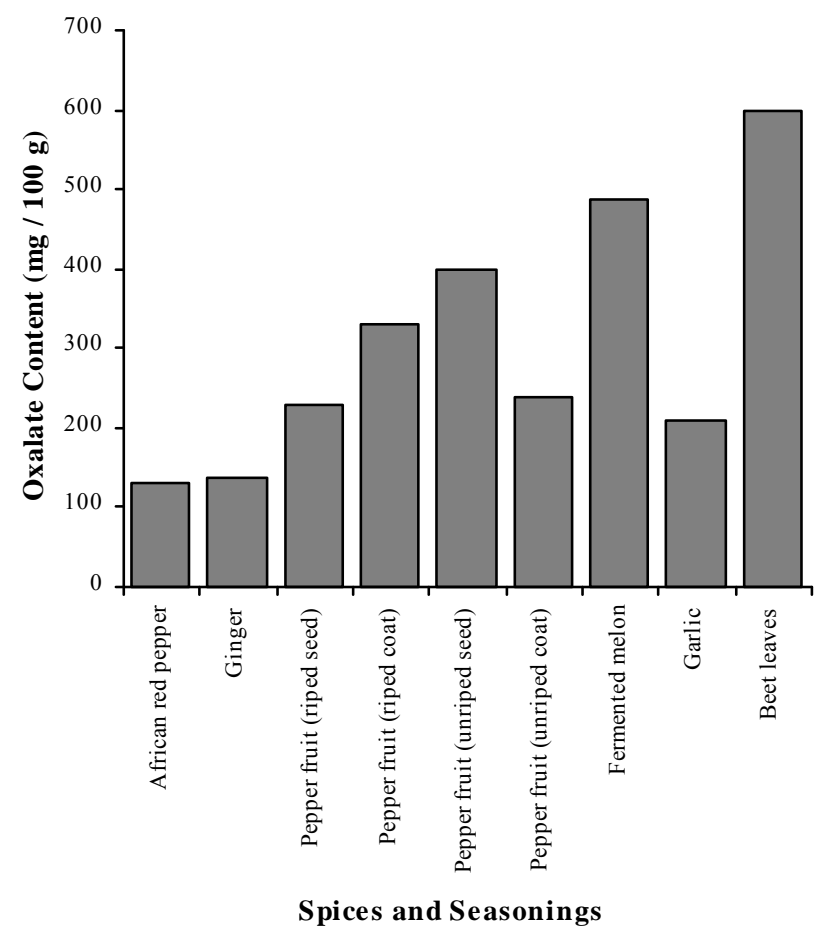

Figure 1: Dry Weight Oxalate Contents of Spices and Seas onings 


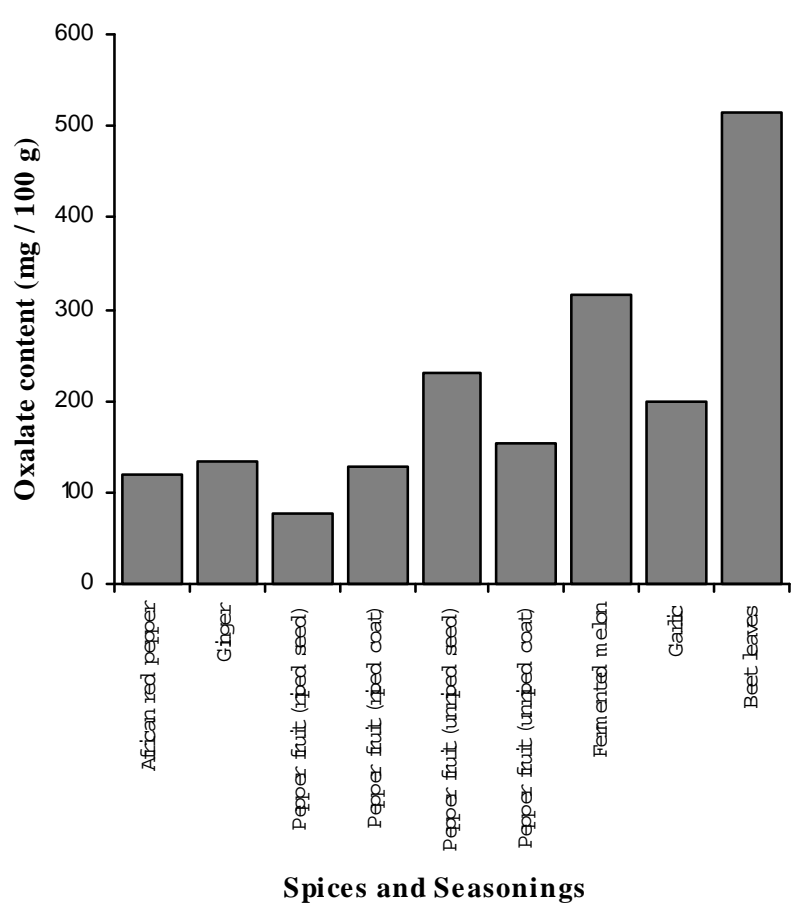

Figure 2: Fresh Weight Oxalate Contents of Spices and Seas onings

\section{REFERENCES}

Allison, M.J., Daniel, S.L. and Cornick, N.A. (1995). Oxalate Degradation Bacteria. In Khan, S.R. (ed.). Calcium Oxalate in Biological Systems. Boca Raton: CRC Press, pp. 53-72.

Andrew, T.C. and Visser, E.T. (1951). Food Research. pp. 305-306.

Chai W. and Liebman M. (2005). Oxalate Content of Legumes, Nuts and Grain-based Flours. Journal of Food Composition and Analysis 18: 723-729.

Charrier M.J.S., Savage G.P. and Vanhanen, L. (2002). Oxalate Content and Calcium Binding Capacity of Tea and Herbal Teas. Asia Pacific J. Clin. Nutr. 11(4): 298-301.

Concon, J.M. (1988). Food Toxicology: Principles and Concepts. New York: Marcel Deeker. pp. 56-59.

Curham, G.G. (1999). Epidermiologic Evidence for the Roles of Oxalate in Idiopathic Nephrolithiasis. J. Endourol 13 (9): 29-31.

Fasset, D.W. (1973). Toxicants Occurring Naturally in Foods. 2nd ed. Washington: Washington Academy of Sciences. pp. 346-362. 
Holmes R.P. and Kennedy M. (2000). Estimation of the Oxalate Content of Foods and Daily Oxalate Intake. Kidney International 57: 1662-1667.

Lane, B.G. (1994). Oxalate, Germin, and the Extracellular Matrix of Higher Plants. FASEB J. 8: 294-301.

Liebman M. (2002). The Truth about Oxalate. The Vulvar Pain Newsletter, Number 22, 2-3. Obtainable at http//www.vulvarpainfoundation.org/vpfoxalate.htm.

Linder, M.C. (1991). Nutritional Biochemistry and Metabolism with Clinical Applications. 2nd ed. New York: Elsevier. pp. 101-103.

Massey L.K., Palmer R.G. and Horner H.T. (2001). Oxalate Content of Soybean Seeds (Glycine max: Leguminosae), Soyfoods, and Other Edible Legumes. J. Agric. Food Chem. 49 (9), 4262-4266.

Munro A. and Bassir O. (1969). Oxalate in Nigerian Vegetables. West African Journal of Biology and Applied Chemistry 6: 36-40.

Nnanna, J.E. (1968). Foods of Plant Origin. Nsukka: Afrobis-Orbis Publications Limited. pp. 31-34.

Noonan, S.C. and Savage, G.P. (1999). Oxalate Content of Foods and its Effect on Humans. Asia Pacific J. Clin. Nutr. 8: 64-67.

Nwaiberi-Onunuju, J. (1996). Vegetables and Fruits in Meat Preparation. Owerri: Alvan Ikoku College of Education Publishers. pp. 21-25.

Oyenuga, V.A. (1968). Nigeria's Food and Feeding Stuffs: Their Chemistry and Nutritive Values. Ibadan: Ibadan University Press. pp. 20-25.

Parker, S.P. (ed.) (1980). McGraw-Hill Encylopedia of Science and Technology. Vol. 12. p. 593.

Ritter M.M.C. and Savage G.P. (2007). Soluble and Insoluble Oxalate Content of Nuts. Journal of Food Composition and Analysis 20: 169-174.

Sanz, P. and Reig, R. (1992). Clinical and Pathological Findings in Fatal Plant Oxalosis. Am. J. Forensic Med. Pathol. 13: 342-345.

Watanebe, Y. Uchiyawa, F. and Yoruba, K. (1994). Compositional Changes in Spinach (Spinacia oleracea L.) Grown in the Summer and Fall. J. Jap. Soc. Hort. Sci. 8: 889-895. 